\title{
Counselling a Woman Traumatized by Severe Abuse
}

\author{
Jodi Bryant \\ Life Change Resources, Saskatoon, Canada \\ Email: Jodi@lifechangecounsellingresources.ca
}

Received 25 February 2014; revised 21 March 2014; accepted 15 April 2014

Copyright (C) 2014 by author and Scientific Research Publishing Inc. This work is licensed under the Creative Commons Attribution International License (CC BY). http://creativecommons.org/licenses/by/4.0/

(c) (i) Open Access

\section{Abstract}

The manuscript is a case report on a newly married Christian wife and mother of 3 children who sought help at a college counselling service for substance dependence and marital problems. Her past sexual trauma had manifested as severe traumatic reactions, which had contributed to a chronic emotionally distressed life, sexual promiscuity, and substance dependence, and she was unable to function appropriately in most spectrums of vitality. After the case issues and counselling approaches were researched, family members attended 11 Christ-centered or Spirituotherapy counselling sessions during which theistic and CBT interventions were used. The client gained insight into her past and current issues; grew spiritually; decreased her substance use; gained better communication skills, parenting, and coping methods; maintained a part-time job; and learned relapse prevention and management strategies. It was recommended that she continue theistic counselling.

\section{Keywords}

\section{Sexual Trauma, Substance Abuse, Spirituotherapy, Theistic Interventions, Spiritual Counselling}

\section{Introduction}

Ana*, a 33-year-old distressed woman who was desperate for help for her addictions, consistently overwhelmed, and emotionally erratic, was referred to me at a local college counselling center by a faculty member. Ana had been searching for a Christian counsellor and the faculty member shared with her that the author was being trained as a professional counsellor and that the author shared the same Christian faith and values as she did.

\footnotetext{
*All names and identifying information have been changed to protect the identities of the case participants.
} 


\section{Literature Review}

\subsection{Sexual Trauma and Post-Traumatic Symptoms}

Traumatic abuse can be sexual (rape, sexual assault, sexual abuse, and domestic or partner violence, physical, neglect, emotional, spiritual, and psychological [e.g., berating, humiliating, threatening, abandoning, confining, and verbal]). Sexual trauma, especially for women, is a major contributor to Post-Traumatic Stress Disorder (PTSD) (Matsakis, 1996). Matsakis defines sexual abuse as "unwanted sexual contact of any kind, regardless of the victim’s age, sex, or relationship with the abuser” (1996: p. 289).

The Diagnostic and Statistical Manual of Mental Disorders (DSM-V) (5th ed.) (American Psychiatric Association [APA], 2013) states that PTSD involves exposure to actual or threatened death, serious injury, or sexual violence and subsequent symptoms that last more than a month, including impaired functionality; distressing memories, persistent ongoing reactions, triggers, dreams or flashbacks; efforts to avoid persistent distressing feelings or thoughts; persistent negative distorted beliefs and emotional episodes; and feelings of depersonalization or derealization. Brown, Williams, Bray, and Hourani (2012) define PTSD as “...psychological consequences of exposure to stressful events” that an individual experiences as traumatic (p. 1184). Responses are influenced by the "intensity of the experience, its duration, and individual difference (e.g., coping, social support) (p. 1184). Some people may demonstrate some PTSD symptoms yet not meet the diagnostic criteria for PTSD.

Both Wright (2011) and Matsakis (1996) believe that rape, sexual assault, sexual abuse, and domestic violence, or sexual trauma, can severely affect the victim negatively to the point of inducing symptoms similar to PTSD and potentially, triggering PTSD.

Unresolved trauma can negatively affect reactions to others and the ability to trust, and can cause great turmoil in a marriage relationship, resulting in "verbal and physical abuse to vent [their] inner rejection” (Pringle, 2013: p. 23). Unresolved trauma can also cause irritability, restlessness, outbursts of anger, rage, aggressiveness, mood swings, feelings of helplessness, control and power issues, and the tendency to isolate with feelings of detachment, numbing or restricted range of feelings (e.g., disconnecting, cutting or scarring). Self-destruction, suicidal behaviour, death wishes, difficulty concentrating or remembering, disorientation, depression, shame, self-blame, false and genuine guilt, low self-esteem, identity issues, difficulty in relationships, and lack of ability to connect on a heart-to-heart level can also occur. Spiritually, the ability to hear God's voice and receive His blessing can be hindered. Furthermore, unresolved trauma can affect the ability to trust, have hope, and to rest (EH, 2009).

\subsection{Post-Traumatic Risk Factors}

Post-Traumatic risk factors include: a) Prior trauma and poor emotional adjustment; b) Severe physical injury and perceived life threat or horror during traumatic occurrence; c) Perceived post-trauma care; and d) Female gender and certain genotypes (APA, 2013; Breslau, Davis, Andreski, \& Peterson, 1991; Brewin, Andrews, \& Valentine, 2000; Bromet, Sonnega, \& Kessler, 1998; Elijah House, 2009; Kessler, Chiu, Demler, \& Walters, 2005; Kessler, Sonnega, Bromet, Huges, \& Nelson, 1995; Kilpatrick et al., 2003; Norris, 1992; Ozer, Best, Lipsey, \& Weiss, 2008; Resnick, Kilpatrick, Dansky, Saunders, \& Best, 1993; Steinbuchel, Wilens, Adamson, \& Sgambati, 2009).

Mueser, Rosenberg, Jankowski, Hamblen, and Descamps (2004) said that those with severe mental illness (SMI) like Bipolar Disorder (BD) have had excessive exposure to trauma in their lives. Thus, their risk for PTSD is increased. Further, studies by Steinbuchel, Wilens, Adason, and Sgambati (2009) investigated the causal relationship between BD, PTSD, and Substance Use Disorder (SUD). They concluded that there was an increased rate of PTSD in adolescents with BD and that those who had both PTSD and BD developed "significantly more subsequent SUD” (2009: p. 198). In addition, females exposed to a traumatic event before the age of 17 (40\% - 76\% of children), were six times more inclined to develop PTSD (Breslau \& Anthony, 2007; Steinbuchel et al., 2009). SUD rates were higher in the BD samples with than without PTSD.

\subsection{Substance Abuse/Addiction Problems}

Of those who exhibit symptoms of PTSD, many have comorbid psychiatric disorders, including substance use disorders (Hoge, Auchterlonie, \& Miliken, 2006). Researchers state that the link between substance dependency and PTSD is that substances such as alcohol and marijuana alleviate pain from sexual trauma. Many of the 
women who seek treatment for sexual trauma reported this, according to research by Bonn-Miller, Vujanovic, Boden, and Gross (2011); and Wadsworth, Spampneto, and Halbrook (1995). They further stated that people with substance abuse issues were more likely to have experienced traumatic events than those who did not. The rates of alcohol and/or drug use problems are higher among females with PTSD (Kilpatrick, Acierno, Resnick, Saunders, \& Best, 1997). Wadsworth et al. (1995) concluded that the majority of sexually abused women they investigated were chemically dependent and had a higher propensity of relapsing.

Loneliness, emptiness, angst, low self-esteem, and learned helplessness tend to be commonly reported symptoms for the chemically dependent, as with those who were incest or sexual trauma survivors. A large percentage of individuals drink alcohol and smoke marijuana (Cox, Ketner, \& Blow, 2013). Substance abuse can also increase the risk of physical or sexual assault (Kilpatrick et al., 1997).

Stewart (1996) found a link between PTSD and alcoholism. PTSD sufferers may use alcohol to self-medicate following a trauma. Data from her studies suggest that individuals exposed to trauma are at greater risk for the development of alcohol problems than are individuals who are not exposed. Trauma severity is positively associated both with alcohol consumption following the trauma and with the severity of alcohol-related problems. The individuals "appear to be at significantly elevated risk" (p. 105) for the development of alcohol-related problems.

\subsection{Trauma and Bipolar Disorder}

Bipolar Disorder defined. Bipolar Disorder (BD) is a multifaceted serious mental illness, affecting approximately $4.5 \%$ of the population (Merikangas et al., 2007). BD, affecting both genders equally, is characteristically a mood disorder, where the emotions swing between two poles, ranging from extreme manic highs to severe depressions (Miklowitz, 2011). It can easily be misdiagnosed or incorrectly identified as a plethora of other illnesses, especially if it manifests for the first time in adolescence, which is common because normal adolescence is a "kind of 'psychosis' in itself" (Fawcett, Golden, \& Rosenfeld, 2007: p. 29).

Bipolar Disorder factors. Those who struggle with BD usually have a high comorbidity rate with addiction and substance dependency (National Institute on Drug Abuse [NIDA], 2010), and an increased risk for other comorbid disorders, such as PTSD (Fawcett et al., 2007). Studies show a more severe course of BD for those who are trauma survivors or, trauma-exposed BD clients (Maguire, McCusker, Meenagh, Mulholland, \& Shannon, 2008). Also, Larsson et al. (2013), stated that the BD subjects they investigated who had been physically, sexually, emotionally abused, had an acceleration of BD onset, an increase in self-harm, and more intense mood swings. Additionally, elevated rates of PTSD were evidenced, as was alcohol dependence (Maguire et al., 2008; Otto, Perlman, Wernicke, Reese, Bauer, \& Pollack, 2004) in clients with BD. The initial onset of BD occurs in childhood or adolescents in about 50\% of patients (Miklowitz, 2012). Earlier onset of BD may increase the risk of marijuana use, which may trigger BD for those who are susceptible (Lagerberg et al., 2011).

\subsection{Marital Problems}

Significant relational dysfunction can result from trauma exposure, PTSD symptoms, substance dependency, and mental health symptoms like BD. Relationships are challenging enough without the influence of trauma, substance abuse, or mental disorder. Those who have been sexually traumatized, are substance dependent, and have bipolar symptoms will undoubtedly experience dysfunction in their relationships (APA, 2013; Burns, 1999; Pringle, 2013). Hamblen's research states that a sixty times more likely increase exists in marital problems for those who have PTSD (2013).

In the Sullivan and Miklowitz study (2010), families with an adolescent with BD were examined. High levels of criticism, hostility, and heightened emotional sensitivity were usual, as reported by the families. Those with BD were five times more likely to develop SUDs and relapse, commit suicide, and exhibit poor psychosocial functioning (Goldstein et al., 2008).

Collins, Ellickson, and Klein (2007) found that alcohol intoxication was related causally to divorce among young adults. Substance abuse was one factor. Using alcohol and/or drugs, like marijuana, had an effect on the quality of the marriage. For example intimacy and relationship skills may be hindered, there may be health and legal issues, lack of employment security may exist, and intimate partner violence or domestic abuse may be present.

Research by Cox, Ketner, and Blow (2013) says that divorce can be attributed to substance dependency. It is 
third to incompatibility and infidelity. Over 30\% claim that alcohol is one of the main sources of conflict in a committed relationship. Furthermore, one spouse can negatively influence the other's substance use. In marriages, drinking seemed to serve as a social outlet. On the surface marriages may seem to lack communication, quality time, or exhibit violence, but the root problems are the substance abuse and its detrimental effects on the union. Furthermore, substance dependency can be a form of escapism from unresolved issues such as lack of forgiveness, shame, pain, rejection, suppression, regression, identity, guilt, anger, and grief (EH, 2012; Schafer, 2011). Untreated mental illnesses can also contribute to marital breakdown.

Fals-Stewart (2013) believes that couples in which one or both partners abuse alcohol or marijuana, are very unhappy. Their quality time disintegrates, and an emotional distance grows. Fighting and arguing are part of the daily framework, with violence or anger usually present to some degree. The addict tries to reduce stress by using substances, but the effect of the substance use creates conflict and a downward spiral results. The couple becomes isolated and they co-dependently cover for one another. Money problems usually exist, family and work routines are inconsistent, and household responsibilities are neglected. Post-recovery, there is usually still fighting, arguing and the need to reduce stress, and the addict relapses. Sobriety, though highly significant, it is just a beginning step toward a healthy relationship.

Schafer's (2011) research findings revealed that addiction affects families and that there is a link between disrupted family relationships, marital breakdown, alcohol, and other substance addictions. His results showed that marital breakdown was one way that families were affected by substance dependence. Kosten, Jalali, Hogan, and Kleber (1983), too, confirm that substance dependency does contribute to family breakdown. Most participants in the Higher Ground Alcohol and Drug Rehabilitation Trust in New Zealand had experienced past painful traumatic experiences, which contributed to their addictive cycles and lead to severe family disruption. Most participants revealed the following four main themes: a) Traumatic childhood and adolescent experiences with parents who were also addicted to alcohol and drugs (most experienced physical, sexual, and personal neglect and they coped using alcohol and other drugs); b) Emotionally distant or abusive family-of-origin relationships; c) An inability to develop functional intimate couple relationships due to learned negative relationship patterns, financial stress, and the inability to resolve conflict in a healthy way; and d) Destructive parenting styles (neglecting or abusing their own children) as a result of unresolved issues from their families of origin.

\subsection{Therapeutic Approaches for Trauma-Related Issues}

Spirituality. Scazzero (2006) speaks of the "tip-of-the-iceberg spirituality." This is when people are infants emotionally and spiritually, whether they are unaware, immature, and unwilling to face, or cannot see the truth of their “deep layers beneath our day-to-day awareness" (p. 7). They may change the tip-of-the-iceberg behaviour (10\%) visible to others, but the change is short-term unless the problems $(90 \%)$ below the surface are addressed. The behaviour is the peak, but underneath is the body and base of the iceberg, where the inner spiritual work must be done in order to proceed to a positive outcome of long-term change where choices and actions can be affected.

Psychologists, such as Solomon (1991), Sperry (2012), and Collins (2007) agree that there are causes to spiritual problems and utilizing spiritual interventions, through a theistic counsellor, could facilitate resolutions to them.

Theistic interventions. Research by Appleby \& Ohlschlager (2013) concluded that religion positively influenced human relationships in almost 3,000 scientific studies conducted in the $19^{\text {th }}, 20^{\text {th }}$, and $21^{\text {st }}$ centuries, resulting in "greater overall well-being, optimism and life purpose, increased self-esteem, better adaptation to bereavement, healthier social support, lower rates of depression, fewer suicides, less anxiety, substance abuse and crime, and stronger marital happiness and stability” (p. 370). Theistic meditation has been found to enhance mood, memory, and cognition, autonomic activity, spiritual health, and quality of life (Burns, Lee, \& Brown, 2011; Hussain, 2011; Koenig, 2009; Newberg, 2011). Theistic psychotherapists believe that God created human beings and God's power can transform and enrich the therapeutic experience.

Richards and Bergin (2005: p. 19) believe that the theistic view of human nature and of the world has "profound positive implications for personality theory, psychotherapy, and the processes of healing and change.” Sperry (2012) states, “...therapists are now expected to practice spiritually-sensitive psychotherapy in a competent manner from the first session to termination” (Back cover). Fawcett, Golden, and Rosenfeld (2007) emphasize the importance of being aware of the inner self and that reactions are a direct expression of it. As new 
technology evolves, spiritual interventions become commonplace and therapists develop spiritual competency, the mental health field could see an influx of theistic therapists. Hence, the mainstream field of counselling could flourish in ways yet unseen—a new dimension of long-term theistic healing might evolve.

Spirituotherapy. Spirituotherapy, developed by Solomon (1991), evolved in the 1970s. Spirituotherapy is based on the view that humans live in an interconnected, relational universe where humans have been created by God to be connected to self, one another, and God. Without connections people are isolated and lose their purpose and meaning. This can lead to a mode of escapism where they can be seduced through false feel-goodfor-the-moment experiences with substances, illicit relationships, sexual addictions, attempts to achieve impossible ideals of perfection or performance, resulting in a downward spin cycle of trying to feel better in their lacunae of pain and emptiness. The process of Spirituotherapy discovers presenting problems and addresses our need to surrender our life to our Creator God, restoring our true spiritual identity by the power of the Holy Spirit through theistic interventions; thus transforming and liberating us from the false beliefs, thoughts, and unhealthy patterns that once hindered us.

Other therapies. Trauma survivors, addicts, and those with a severe mental illness such as BD can cope and manage their health, stress levels, relationships, and comorbid conditions through theistic psychotherapy. The word "theistic" can be a foundational strategy applied to many other psychotherapies (Cognitive Behavioural Therapy (CBT), Psychoeducation (PE), Family Therapy (FT), pharmacotherapy, Dialectical Behaviour Therapy (DBT), Exposure Therapy (ET), and Eye Movement Desensitization and Reprocessing (EMDR), couples, family or individual) (Collins, 2007; Fawcett et al., 2007; Follette \& Ruzek, 2006; Perkinson, 2012; Wright, 2011). A theistic orientation is distinctly different than other psychotherapies in the acknowledgement that God can divinely intervene through His inspiration and love in helping humans to “cope, heal, and change” (Richards \& Bergin, 2005: p. 154). Theistic strategy applied in psychotherapy can be a beneficial "multidimensional, integrative approach” (Richards \& Bergin, 2005: p. 154).

Cognitive-behavioural therapy (CBT) and PE, in addition to pharmacotherapy, is known to help with issues stemming from trauma, substance dependency, and mental illness. Addicts can gain skills in self-control, coping, relaxation, stress management, time management, and communication through CBT interventions (Collins, 2007; Fawcett et al., 2007; Follette \& Ruzek, 2006; Mueser, Rosenberg, Jankowski, Hamblen, \& Descamps, 2004; Otto et al. 2004). Moreover, NIDA (2010) stated that CBT was a successful treatment for alcohol and marijuana addiction, as did researchers Carroll et al. (2008). Najavits, Weiss, Shaw, and Muenz (1998) demonstrated that women "showed significant improvements in substance use, trauma-related symptoms, suicide risk, suicidal thoughts, social adjustments, family functioning, problem solving, depression, cognitions about substance use, and didactic knowledge related to the [CBT] treatment” (p. 437). In addition, PTSD can be effectively treated in people with mental illness, such as those who with BD symptoms and alcohol dependence due to rape. Hamblen, Jankowski, Rosenberg, and Mueser (2004) concluded in their research of three PTSD case studies, who were severely mentally ill, that PTSD can be "effectively treated" and in addition to pharmacological care, there were "significant improvements" for each one, in the reduction of PTSD symptoms, and "modest improvements" in psychiatric symptoms, and two of the three no longer met the criteria for PTSD 3 months after treatment (p. 147). Additionally, PE tools were known to be effective (Fawcett et al., 2007; Miklowitz, 2008). Both CBT and PE used for those with symptoms of BD showed "significant improvements" in a randomized controlled study involving 100 subjects during a 14-week treatment assessing "quality of life, illness concepts and compliance for medication” (Lenz et al., 2009: p. 11).

Educating the client and family and providing relevant information on substance abuse, mental illness, and trauma reduces confusion and augments understanding. Family-focused PE helps families exhibit more healthy interactional behaviour. For example, a client would learn to identify her symptoms, feelings, and see that substance dependency can be a coping response for feelings of guilt, shame, and underlying trauma. Educating and understanding commonalities evident in illnesses like BD, such as the environmental challenge on the family system, the recovery process, and the absence of healthy communication and problem-solving skills strengthens awareness and coping ability (Fawcett et al., 2007). An outcome of greater hope and understanding of a client's issues are anticipated after educational sessions.

Miklowitz (2008) offers the client and the family information about "the biological interactions between drugs, alcohol, and mood disorder...." and how "substance or alcohol abuse may aggravate illness-based neurophysiological dysregulations and interfere with the efficacy of the patient's medications” (pp. 302-303). He gives examples and handouts to complement the educational process. Families can benefit from Family Therapy 
([FT], Perlick et al., 2010). Family members are often caregivers experiencing high levels of emotional distress (89\% - 91\%). Many lack education. With an educational phase, they learn the causes, course, and treatment of the illness. Then they can work through communication barriers and false beliefs (Depoy, 1999; Miklowitz, 2008).

Combining FT and PE treatment with pharmacotherapy lowered the likelihood of one's being rehospitalized and lowered the relapse risk compared to individual treatment and pharmacotherapy (Rea et al., 2003). CBT, PE, and pharmacotherapy, according to Zaretsky, Lancee, Miller, Harris, and Parikh (2008), may be a beneficial treatment in reducing symptoms similar to BD, be safer, and more acceptable to clients than solely pharmacotherapy. Their research results were "clinically significant” and "consistent with previous studies" indicating that "CBT has efficacy” in the treatment of symptoms similar to BD (p. 447). BD has a high prevalence of comorbid conditions, so pharmacotherapy alone does not achieve long-term recovery.

Adopting and applying an ethical and effective theistic foundation to other therapies can be beneficial in assisting clients to become more self-aware of their spirituality, which can support their healing process.

\section{Case Information}

Ana is an English Caucasian prairie-raised Canadian of average height and medium build. When the author met Ana, she appeared upbeat. She dressed casually and plainly. The author found her to be personable and amiable, though rushed and anxious. She lived with Matt, her husband of 2 years, and her three children, John (14), Ned (12), and Sally (9). Ana had joint custody with the father of Ned and Sally.

The first three times we met were dedicated to intake and assessment. As a result, during our intake period, the author interviewed Ana and administered the Life History Questionnaire ([LHQ], Elijah House [EH], 2013), to obtain personal and family background information; the Spectrum of Vitality the Intake Questionnaire (Author, 2010), to identify which areas of her life were needed to be addressed first (spiritual, emotional, relational, physical health or wellness, occupational, or financial); The Daily Spiritual Experience Scale ([DSES], Underwood \& Teresi, 2002), to understand her views on spirituality; The Depression Anxiety Stress Scale-42 ([DASS42], Akin \& Çetin, 2007; Crawford \& Henry, 2003; S. Lovibond \& P. Lovibond, 1995), to identify problems with anxiety or depression issues; and the Communication Pre-Questionnaire from the Minnesota Family Study Center (S. Miller, P. Miller, Nunnally, \& Wackman, 1991) to determine how she communicated to her husband.

For a section of the LHQ, Ana created a genogram. The genogram was developed by Murray Bowen who believed that multigenerational patterns could influence how a family functions $(\mathrm{H}$. Goldenberg \& I. Goldenberg, 2013). A genogram is a "visual map of family dynamics and relationships among a minimum of three generations” (Casado-Kehoe \& Kehoe, 2007: p. 20). Genograms use a “symbolic coding system” (p. 21) based on "patterns of interaction, family relations and structures, alliances, triangles, closeness, conflict, emotional reactivity, medical and mental illness, addictions, pathology, strengths, educational and career paths, religious affiliations, and cultural background...” (p. 20) and "learned lifestyle patterns" (p. 19). Family systems therapists use the genogram to reveal familial interactive relationships, expose generational patterns, and highlight other family-of-origin commonalities (C. Klystra \& B. Klystra, 2001; Elijah House, 2012; Goldenberg \& Goldenberg, 2013; Hovell-Dew, 2006; J. Sandford \& P. Sandford, 2008; Murphy, 1992; Smith, 2012). By graphically diagramming at least three generations, one can see problems symbolically presented and passed down (Goldenberg \& Goldenberg, 2013). Genograms can also be used as a psychological tool for mapping diverse cultural heritages and exploring issues of spirituality (Lim \& Nakamoto, 2008; Willow, Tobin, \& Toner, 2009).

\subsection{Family and Mental Health History}

Ana’s parents married when Ana's mom was 4 months pregnant with her. Ana's birth came late; she weighed 8 pounds. She was born in a coastal city in British Columbia's northwest.

Ana was an average student. School was "hard, tormenting, and lonely.” She was bullied and saw herself as “a doormat.” Regular transfers in her father's career resulted in Ana being moved between British Columbia and Saskatchewan seven times before her Grade 12 graduation in Saskatoon, disrupting her social and academic life. After high school, she attended a local bible college but dropped out within the first few months due to a traumatic assault at her part-time job by her employer.

Mental illness, anxiety, and divorce were patterns on both sides of Ana's family, according to her genogram. Alcohol abuse was in her mother's family line. All of Ana's siblings struggled with Bipolar Disorder (BD) and substance dependency. Ana’s maternal grandfather committed suicide, and one of Ana's siblings made a suicide 
attempt. Incest and sexual promiscuity were present on her father's side.

The LHQ indicated a history of traumatic emotional, physical, and sexual abuse from past men. Furthermore, serious health issues and current addictions to tobacco, alcohol, and marijuana were revealed.

Results on the DASS-42 showed that there was no evidence of depression, but test results indicated the presence of chronic anxiety.

Ana said that she had seen counsellors in the past but she was never able to relate to them. She mentioned that she had not been willing to change then, but she was now.

\subsection{Abuse, Sexual, Addiction History, and Status}

In Grade 2, a young girl sexually explored Ana’s body. From then on Ana explored boys and girls sexually, and allowed boys to touch her because she found it "difficult to say no" to them. In Grade 9, Ana experimented with masturbation and liked the feeling but felt it was wrong. Ana was teased and bullied for how her nose and body looked. She struggled with poor self-esteem.

At age 15, in Grade 10, Ana had her first boyfriend, Cal, and she remembers feeling pressured to have sexual intercourse. Her boyfriend and two of his friends allegedly drugged and raped her at a party. She became pregnant and miscarried. Ana began drinking alcohol excessively and socially smoking cigarettes to "numb the pain" of the rape and struggled with "bouts of depression." Concurrently, her physician prescribed Celexa and Seroquel. She became sexually promiscuous, often having 3 - 5 partners a night. She counted at least 50 sexual experiences between the ages of 16 and 17 .

At age 17, while in a relationship with Carl, a drug-user, Ana had a drunken romantic one-night stand with an acquaintance named Dan and became pregnant. Both men were 10 years her senior. While 8 months pregnant Ana had an incestuous relationship with an older cousin. When the baby (John) was born, paternity tests established that Dan was the father. Ana married Carl at age 19. Their marriage was tumultuous. Carl burned Ana with a curling iron and consistently abused her spiritually, emotionally, physically, and sexually. Neither partner was faithful. In particular, Ana cheated with Carl's best friend, Tom, and at age 25 became pregnant with Ned. Paternity tests confirmed that Carl was Ned's father. During the pregnancy, Ana began having severe panic attacks due to Carl's abuse. She had other affairs, including with Carl's neighbour, Steve, for 2 years. She became pregnant and miscarried four more times. When Carl found out about the affair with Steve, he reportedly brutally raped her anally and vaginally. Ana did not charge Carl. She became pregnant with his twins at age 27. Intimate partner violence during the pregnancy lead to a hospitalization, the loss of one foetus, and the discovery of cervical cancer and endometriosis. Ana struggled with severe pain from the cancer and endometriosis. Morphine, Percocet, Delaudid, and Oxycodone, and medical marijuana were prescribed for pain. She became addicted to the marijuana.

During Carl and Ana's 8-year rocky marriage relationship, while pregnant with Sally, Carl pointed a gun at Ana twice, once following his discovery of her affair with his best friend, and once after she moved in with his neighbour, Steve. Soon after the second gun incident with Carl, an older man forced sex on Ana at a party on an isolated farm. She remembered being sober and when she called for help, no one came to her aid. Reoccurring flashbacks and insomnia ensued.

Two months after the farm incident, Ana reported that she was physically assaulted and sexually abused by a police officer. She engaged in swinging and extreme sexual experimentation with countless partners. She was regularly intoxicated to numb and escape from her physical pain and past traumas.

After Sally was born, Ana began relieving her pain with food and became obese. Ana's weight fluctuated dramatically; at one point she weighed over 400 pounds. She had a hysterectomy and a breast reduction. Her excessive drinking and social smoking continued. A year after Sally was born Ana had a two-year sexual relationship with Neil. They had been living together for 7 weeks when Ana found out that he had cheated on her with her sister and countless others. Ana eventually found out that he also had a pregnant girlfriend and terminated the relationship.

The night she left Neil, she met her current husband, Matt. They drank, smoked marijuana, ingested Psilocybin or "magic mushrooms," and were sexually involved within 2 weeks. Matt's ex-wife would not sign the divorce papers, so Matt and Ana went on a "honeymoon" before their wedding with another couple. During the trip, Ana had an affair with the husband.

Two years ago, at age 32, Ana married her current husband, Matt. She felt safe, loved, sexually fulfilled, and 
committed, but they often fought and she secretly cheated on him. Though Ana wanted to change her life, she continued to relapse and engage in marijuana and alcohol use.

Ana's healing was hindered by her fear, her past choices and their consequences, her lack of skills and boundaries, her immaturity and unresolved, unidentified pain, in addition to limited support, knowledge, and understanding of her issues.

\subsection{Religious Affiliation and Status}

Ana considered herself a born-again, spirit-filled Christian. She attended a Pentecostal church. She had positive childhood memories of church events. Ana indicated in the LHQ, the Spectrum of Vitality assessment, and the DSES that her spiritual and emotional health were her highest priorities needing attention. She believed that she needed to be accountable and make her spiritual growth a priority. Moreover, the results of the DSES showed that Ana was highly committed to her faith in God and church attendance, and that her spiritual beliefs gave her a sense of great joy and purpose. The results of the DSES also indicated that a healthy spiritual life was more important to her than wealth, she desired to become closer to God, have a more active prayer life, and participate more consistently in church activities. She reported that God's presence gave her comfort, strength, and peace.

\subsection{Vocational History and Status}

Ana had never sustained long-term employment, which she attributed to unspecified "family issues" and sexual assaults at assorted workplaces. She feared being sexually assaulted again but she planned to work as an education assistant full time in the fall.

\subsection{Hobbies}

She enjoyed ribbon dancing, listening to inspirational worship music, working with young special needs children, baking, singing, sewing, and playing baseball.

\subsection{Goals}

Ana wanted to become more disciplined spiritually, understand her mental illness, learn self-control, develop life management and communication skills, heal from her past unresolved issues, and be freed from addictions.

\section{Case Analysis}

Ana was aware that her addictions had negatively affected her in the past, might be harming her children now, and might destroy her marriage. Her emotions had been unmanageable since age 16. She stated that she would be willing to put in the effort of a 10 into counselling and commit completely.

In addition to Ana's spiritual and emotional issues, her addictions were controlling her and her marriage was falling apart, her children were confused and worried, and she was manifesting symptoms she could not understand. She was not aware how trauma exposure had affected her. The literature the author reviewed lead her to believe that Ana's past trauma exposure and substance dependence were important to address along with teaching survival skills to assist her family and their "prone-to-failure" marriage. Due to lack of time, resources, and focus, the opportunity to address everything was not attainable. Since it was Ana who requested counselling for herself, her issues were prioritized. It was evident that Ana had experienced various traumas and had endured lengthy traumatic abuses. She reacted by abusing substances or running into another man's arms. Ana's family had a history of psychiatric mental distress. Her life had been threatened on numerous occasions, and post-trauma care was limited, since she rarely reported the crises. A lack of resolution of sexual assaults in the work place and rape incidents she reported to authorities reduced Ana's sense of trust. She felt betrayed and neglected by men and the justice system. Moreover, the men she had chosen tended to be abusive. Hence, her fear increased, as did her substance dependency, and her inability to trust. The result was unresolved resentment, anger, and bitterness. Thus, her symptoms intensified. Experiencing abuse, suffering from PTSD-like symptoms, dependency on substances, and the possibility of $\mathrm{BD}$, without the necessary management skills, had been factors holding Ana back from healing and reaching her true potential. Believing the foundational lie of being unworthy and bad, and having deep feelings of rejection, seemed to be a weed rooted deep within her belief system. 


\section{Counselling Plan}

Because of the author's belief system and Ana's request, the author decided to use theistic counselling using a "grace-oriented” process centered on "the Cross of Christ," namely Spirituotherapy. The author decided to incorporate individual, couple, and family modalities. The author created a spiritually safe, trustworthy environment where the author could meet Ana where she was at, nurture her emotional (Goleman, 1994) and spiritual intelligence (Goodson, 2012; Nelson, 2010), and work collaboratively within her framework of beliefs (Richards \& Bergin, 2005; Sperry, 2012). The author seemed that Ana's lack of understanding of her identity in Christ held her back from forgiving, accepting, and loving herself. Spiritual growth and religious growth are known to improve self-esteem, meaning, purpose in life, ability to be alone, and understanding of eternal perspective (Schiraldi, 2009: p. 345). The author felt it was important for her to address Ana's problems that were affecting her spiritually, psychologically, behaviourally, and socially (Aten, McMinn, \& Worthington, 2011; Collins, 2007; Elijah House, 2011; Pringle, 2013; Richards \& Bergin, 2005; Sperry, 2012; Wright, 2011).

The author decided to adopt Spirituotherapy as my main theistic process when working with her client. The author introduced spiritual practices and interventions (e.g., prayer, forgiveness and repentance, worship and ritual, spiritual journaling, fellowship) and began the process of healing by acknowledging potential spiritual issues and addressing the spiritual dimension and its formation in the client's life, using theistic interventions (Richards \& Bergin, 2005). Assessing the client spiritually gave me a focussed direction.

The author's plan was to help Ana grow spiritually by helping her understand her true identity in Christ, develop spiritual practices, restructure her thought processes, introduce communication strategies, help her family cope, educate her and her family on the affects of trauma and substance abuse, provide addiction prevention strategies, and manage her mental health issues, while holding Ana accountable to meet her goals.

The author integrated elements of theistic CBT, PE, and FT that was appropriate for Ana. The author wanted to help Ana through her traumatic experiences by assisting her in forgiving herself, God, and the perpetrators; repent for her negative responses and reactions; and reclaim her true identity in Christ; educate her on necessary skill-sets so as to function in a healthier, more appropriate way; and help her rebuild her damaged marriage.

\section{Intervention}

Ana and other family members attended 11 counselling sessions lasting from 90 minutes to 2 hours each. Sometimes multiple family members were seen during a single session. Ana attended 6 individual sessions. Ana cancelled four personal appointments. Ana and Matt attended 3 couple's counselling sessions. Ana and the children attended 3 family counselling sessions. Matt and the children attended one family counselling session. The children attended one joint counselling session and 3 individual counselling sessions. Between sessions, the family members telephoned, emailed, and sent text messages. All sessions began and ended with prayer.

\subsection{Session One}

Ana and Matt were present during this session. Over the course of 2 hours, Ana, Matt, and the author talked about their desire to make their marriage work. Both were committed to put in a strong effort. Ana shared that she had and upcoming psychiatric appointment and the author encouraged her to keep it.

\subsection{Session Two}

The 90-minute session was divided between Ana (30 minutes), her three children together (15 minutes) and her children separately (15 minutes). Ana shared about the psychiatrist appointment she had and that her psychiatrist prescribed mood stabilizing medication. There was a discussion of Ana's family genogram and her addictions and mental health history, in addition to the generational patterns of anxiety, divorce, and incest. Her intense emotions and poor coping strategies were also discussed. The idea of extending her quiet time with God and her dancing to worship music was discussed. A time of spiritual journaling was implemented and taught as a meditational two-way communication with the Holy Spirit where hearing the voice of God is practiced together, and then a sharing time of what was sensed is communicated. For Ana, there was a confirmation that she had unresolved issues of unforgiveness. After the discussion of what forgiveness and repentance was and wasn't, the author lead her through a process of forgiving herself, God, and those who had abandoned, rejected, or abused her. The author gave materials on forgiveness, repentance, and generational sin. 
When the author met with the children, the author gave them an opportunity to share their concerns. They were worried about their mom's cancer returning and that she might die soon. They were worried about their mom and step-dad separating, and about their constant fighting.

The author met with each child individually and asked what he or she would change in their family if they had a magic wand. During John's time he started to cry and expressed his anger towards his step-dad. He felt that he was very unfair, had too many rules, assigned John too many chores, and should not make him exercise an hour each day. He was nervous and needed to vent. The author let him cry and encouraged him to communicate to his mom and step-dad how he was feeling. The author offered to help him plan a time for this. The author asked if he would like his mom to join the session so he could share his concerns with her, and he agreed. His mom came in and it was decided that they would share his concerns with Matt this week. He relaxed and shared his gratitude for the session.

During Sally's session, she openly shared about the changes she wanted to see. She wanted to change the food choices at home. She also shared that she feared her biological dad who would pinch, yell, and hit both her and Ned. She cried and shared that she loved her dad. She also shared that her step-mom would pull her hair, yell, and punish her unfairly when Sally disagreed or talked back to her. The author listened and then the author asked if she would like to share this information with her mom. Sally agreed and Ana was invited in, but Sally started to cry because she was worried that if her step-mom and dad found out that she was talking about them at counselling they would be angry and yell at her. It was decided that a meeting with Sally's social worker was in order and Ana would set up that appointment.

During Ned's session, he shared that he no longer wanted to visit his biological dad; he only visited because he did not want his sister to go there alone. He was old enough to choose not to go, but Sally was two years younger and did not have the choice. He shared that his dad was mean to them, if his dad found out what Ned had said to the counsellor, he and Sally would "get in big trouble." The author asked Ned if he would like to share this with his mom and he said he would. When Ana came in and heard how Ned felt, she cried because she, too, was frightened of her ex-husband. She had been wondering why the children no longer wanted to visit their dad.

The author invited Ana and the three children to come in altogether at the end of the session. The author asked each child to share what they love about their mother. They each affirmed their mom and then the author brought out a huge wood cross and gave each family member post-its. The author explained how Jesus heals through the Holy Spirit's power and the meaning of the cross. They wrote their issues on post-its, put them on the cross, and then asked Jesus to take them and bring healing to each issue. They wrote, "Help mommy to heal and get better", "Help stop my daddy from doing bad things", "Help us have a happy family and take time to cool down when we need to", and "Help us change to become more like [Jesus].” Their homework was to practice using a "Cool Down Time" strategy respectfully. They were all to read a booklet on anger and email what they learned. The author also gave Ana some family collaborative homework sheets on emotional regulation.

\subsection{Session Three}

The author saw Ana for 1.5 hours and John for 30 minutes. Ana said the family was using the cool-down strategy and it was working. She shared how John had become more relaxed. She also noticed that she had more patience and self-control; she was less overwhelmed, and was able to complete her daily tasks. There was a time of reading scriptural healing affirmations and also a dialogue about financial stewardship, guidelines on parental discipline, and how to run a home. She shared that she was thinking about applying for and going back to work.

During John's session he said that his talk with Matt went well and that there had been many good changes since the last session. He shared that he was feeling less stressed, the chores had been divided more fairly, and Matt was now rewarding him with computer time after John exercised. He now wanted to see his younger cousin and siblings respect his space. The author helped facilitate what boundaries were and what kind would be good to set with them. The author then asked him to share his concerns with his mom in the room, and later with Matt. Different approaches that he could use were discussed and then Ana came in and listened to her son's plight. The author praised John's mature behaviour and clear communication. He glowed and felt empowered. He and Ana were given homework to plan how to introduce and set boundaries with Matt and John's siblings. They were invited to continue emailing or texting. 


\subsection{Session Four}

Ana and Matt attended this 2-hour session. A deep slow breathing technique was taught and practiced so it could be implemented when emotions escalated. Furthermore, there was a conversation on the purpose of anger and how to prevent rage, different ways to apologize, and the fact that people feel loved in different ways. We discussed unhealthy thought patterns and ways to respond differently were discussed. They were given an assignment to document their thought patterns and discuss them with one another. Additionally, they were to meet with their financial advisor and work on their financial situation. They were also to go on a date in the next week and take time to affirm one another. Moreover, Ana was to implement a 30-minute personal quiet time in mental preparation for Matt's arrival home from his long work day. Matt was to work on becoming more sensitive and compassionate towards Ana and her kids.

Time was taken to acknowledge Ana's traumatic past and the theistic process to release her trauma began. Jesus was invited to bring his healing presence and power and manifest Himself as the God of peace in the midst of her trauma. Furthermore, a fervent prayer for release of the fear, shock, terror, and shame within her was spoken, as was a petition for it to be replaced it with peace, love, and comfort. The author educated the two on how this process can prepare the heart to deal with the necessary root issues and provide the courage to resolve the pain of them. Scriptures were given to mediate on for homework.

\subsection{Session Five}

This 90-minute session included Matt and the three children. Ana was at the hospital for ovarian cancer tests. The family shared their worries about Ana's health. Matt shared that his unhealthy thinking was becoming more positive now that he understood that his thoughts could not control him. He has seen positive changes in his family and he wanted to look at his wife's situation with hope. Scriptures on hope and healing were read. The author taught the family a theistic strategy on how to present Ana to the Cross of Christ and the strategy was practiced. For homework the family was to practice demonstrating encouragement and grace for Ana and continue to work on communicating clearly and honestly.

\subsection{Session Six}

Ana and Sally shared the 90-minute session. The author spent 45 minutes with Ana, 30 minutes with Ana and Sally together, and 15 minutes with Sally on her own. During Ana's session the trauma releasing process continued as did working through forgiving the long list of people who had abused her. Sally's session was cathartic. Sally cried and cried about her fear of her biological dad and step-mom and said that she felt safer with her mom and Matt. She was frightened about an incident that happened when she was at her dad's. Her dad threw a bucket of rocks at her step-mom because she was yelling at him, and she tripped and fell down the stairs. She said that her dad and step-mom criticized and shamed her for getting her haircut. Sally explained that when she talked back to her by stating that she wanted it cut and her mom said she could do it, the step-mom took everything out of her room and only let her have an old blanket, a pillow, and the clothes she had brought for the weekend. Again, Sally reiterated that her dad was doing "bad things" and if Grandpa every found out, her dad would be "in big trouble." She was very frightened. The author brought Ana in, and Sally cried in her arms. Sally went out to the washroom and Ana broke down in tears fearing that her ex-husband might hurt her kids. She had talked to Sally's social worker, and Sally's teacher had called expressing concern for Sally's safety when Sally disclosed her dad's abusive behaviour.

\subsection{Session Seven}

This session was 1 hour. The author spent 50 minutes with Ana and 10 minutes with Ned. With Ana there was a discussion on changes she can make to improve her quality of life and how she can implement them. Ana's psychiatrist had increased her prescription to help her cope with her emotions and her possible BD. She shared that her flashbacks were stronger and many memories were coming back, especially of past sexual trauma. She could now feel and label her emotions of anger, bitterness, resentment, and hurt. She realized that she had believed lies about herself. The lies she believed about herself were addressed and the author facilitated the process of Spirituotherapy by helping Ana release her emotions and choose to forgive herself and those who had hurt her. 
Ned and the author talked about his fear of his dad and how much he loved him. The author validated his feelings for his dad and a prayer for healing their relationship was spoken. At first, Ned pretended everything was wonderful with his dad and step-mom, but soon the truth of Ned's anger surfaced. His dad became angry with Ned when he did not visit. There was a time of brainstorming different ways he could tell his mom his feelings and then he invited his mom in to the session so he could share and his mom could hear his heart. Both Ned and Ana were not willing to talk to Carl because of his past hostility, but they were thinking about planning a meeting with Carl in the future with Ned's social worker and Ana's parents. Ana was going to connect with Ned's social worker and gain insight on the issue.

\subsection{Session Eight}

The author and the family ate together, talked about each person's week, and then Ana and the author chatted about some observations of the kids while they played at a table nearby. The author handed Ana some resources on parental discipline for blended families, family communication skills, and relationship building. Next, how to integrate these ideas into their family system was discussed.

After Session 8, Ana left messages cancelling the next four sessions because of scheduling difficulties.

\subsection{Session Nine}

This 2-hour session was with Ana. Ana shared that she tried to hide and escape from her pain by relapsing and that she used marijuana with her sister, who was also an addict. Ana was the one who had introduced substances to her. Matt wanted her to set up strong boundaries with her co-dependent sister, but Ana gave in to her sister's demands. Matt and Ana had quarrelled about the issue. Ana went to her sister's place after the fight. She felt ashamed and angry with herself because Matt was right and she didn't listen to his wise advice. She also felt guilty for recently getting involved with another man. Ana had been having an emotional affair with a man during the month without Matt knowing. We discussed relapse prevention strategies and designed a coping plan for when she faced temptation. She realized that she would need to abstain from situations, which might cause her to relapse. She realized that she must limit her visits with her sister. A prayer for strength to make the right choices was spoken, and then she asked God for forgiveness for her emotional affair. Her homework was to share the plan with Matt. She had not shared with him about her emotional affair and wanted to tell him, so there was e discussion on ways she could communicate in a healthy way what had happened.

\subsection{Session Ten}

This 2-hour session was divided between Ana, Matt, and her children. Ana and the author discussed Matt's reaction to her marijuana and drinking relapse. Matt had been angry and had left her for a day, but eventually forgave her. The author recommended that Ana and Matt book another appointment together.

During Ned's session he shared about the big fight his mom and Matt had. He said that they were fighting about how he used too much cheese. He felt responsible for their big fight and cried. He said that he would never waste cheese again. The author helped him to understand that he was not the main reason for the argument and that there is usually more to an argument than one may realize. His mom came in and Ned shared how sorry he was. Ana said that she and Matt had been angry with one another about some other issues, and she said she was sorry for yelling at him. There was a discussion on how they could have communicated their concerns in a more healthy way.

Sally and the author discussed her feelings about her biological dad. Her dad was not being as mean. She said that she had been praying for him and that sharing her feelings about being afraid of him had helped. Ana mentioned that the social worker had contacted Carl and he was told to treat his children better. Sally also mentioned that Matt and her mom were fighting again. Ana shared with Sally and the author that she was going to try to communicate in a healthier way now that she knows how to.

John shared about his stress at school. He was very anxious about finals week coming up. After mapping out which finals he had and when they were, he shared that they weren't going to be as difficult as he had thought. He realized that the word "finals" had triggered his anxiety. Ways of diffusing test anxiety and incorporating study skills were taught. 


\subsection{Session Eleven}

This was Ana and Matt's last session. During the session the couple reflected and compared their differing perspectives on how they communicate to one another. There was a discussion on how poor communication skills can trigger into an emotionally escalating conflict and strategies on how to diffuse marital conflict and communicate effectively were explored. A prayer for the strengthening of their marriage was spoken.

\section{Results and Recommendations}

It seems that Ana hid behind a fig leaf most of her life, hiding from shame, fear, guilt, and rejection. She had not been able to love herself. Due to many forms of abuse, her emotional and spiritual formation seemed to have arrested.

Ana made a decision to apply spiritual practices to her life. Spiritual progress was demonstrated by her and her family's commitment to go to church every week and to attend a week-long summer family church camp. Additionally, at church, she assisted young children, including her daughter, to learn to ribbon dance during the praise and worship on Sunday mornings. The family also committed to praying together at meals and before bed. Moreover, Ana continued her journaling, and extended her personal prayer and worship times. Devoting their time to these activities brought about a healthier atmosphere in their hearts and home. Fewer emotional outbursts, more direct and healthy communication, a more mature perspective on circumstances, and a more relaxed tone occurred. Ana was receiving better medical care, was working part time, was free of cancer, and was active in baseball and dance. Though she had relapsed once during therapy, she reduced her cigarette and marijuana smoking, and alcohol intake. Her emotions stabilized with the proper medications. She and Matt accepted the author's recommendation to continue therapy, work on healing, and address other unresolved issues.

Research indicated that support group counselling favoured long-term positive outcomes for clients, like Ana, struggling with addictions, past trauma and abuse, and possible mental illness (Collins, 2007; Perkinson, 2012; Pringle, 2013; Schneider-Corey, G. Corey, \& C. Corey, 2010). As a result, the author recommended they continue counselling, join a 12-Step Program (Friends in Recovery, 1988; McVey \& Quarles, 2012), and keep using the tools they had learned.

\section{Discussion}

Theistic interventions, Spirituotherapy, CBT, PE, and FT strategies worked for Ana, in addition to her medication. Ana had experienced many symptoms of PTSD, SUD, and BD (APA, 2013), yet had not been formally diagnosed. Ana had affirmative responses to five of the six screening categories done in a research study on civilian trauma and PTSD (e.g., major life events, rape, sexual molestation, attempted sexual assault, and physical assault) (Resnick et al., 1993). She experienced multiple-event trauma exposure. It could be argued that Ana had BD before her traumatic experiences, since her siblings did. Unbeknownst to Ana, the traumas had a destructive effect on her view of self, God, and others. Theistic counselling assisted her in transformational change.

In the future, the author would, with the client's consent, connect, observe, and sensitively gather more strategic information from other family members. Maybe being raised in a loving, Christian home was the catalyst for Ana's significant transformation and restoration of inner joy. Her relationship with Jesus Christ, though distorted, was genuine and sacred to her and her husband, and her motivation to succeed through this process appears to have stimulated her desire to commit to it, be coached, and grow. With counselling, Ana relapsed less often then when she was not in counselling. When Ana cancelled four sessions, her progress in meeting her therapeutic goals and healing process was interrupted. During the period of time where she did not attend her counselling appointments she relapsed once. She drank alcohol and smoked marijuana.

Restructuring her thoughts about self and God, and helping her understand her true identity in Christ moved her ahead. She was able to reduce her smoking tobacco and marijuana intake, alter her prescriptions, reduce drinking alcohol, begin a job, change her quality of life, and believe in herself. When Ana realized how common her issues were with addicts, divorcees, blended families, those with PTSD, SUD, and BD, and that others had conquered their problems, her perspective adjusted from victim to overcomer, her husband understood what to expect, and transformation occurred. Her functioning and relational skills improved through self-awareness and education. She realized that she has the power and responsibility to make her own choices, and that she is in control of her body and thoughts. People are seeing positive change in Ana and her family. Through the process of theistic counselling, she continues to find freedom. 


\section{Conclusions}

In closing, a plethora of research has evolved over the past decades in support of the healing power of theistic interventions, like Spirituotherapy, which can be used independently or easily integrated with other psychotherapeutic approaches. As a result, the author applied theistic strategies while counselling a Christian wife and mother of 3 who struggled with substance dependence and marital problems due to severe trauma and abuse and sought help at a college counselling service as discussed by the author.

Foundationally, having belief in a God who loves us, has redeemed us, and is willing to restore us gives significant meaning to those in need of hope. Those who are on a spiritual journey with God can risk looking within themselves, changing and moving forward through Divine Intervention and healing. Now that counsellors are expected to integrate theistic interventions, the author is much more optimistic about serving as a theistic therapist and has a sense of newfound freedom.

\section{Acknowledgements}

If it weren't for the gracious participation of the staff and students at a local college, and also the divine connection with Dr. Bruce Pringle, this Master of Arts in Counselling Psychology internship might not have been as it was-a powerful experience where lives were, and continue to be, significantly transformed. This was empowering and meaningful. The author relished being a part of the team at the college.

Additionally, thanks to Dr. Bruce Pringle, esteemed by many, for his instrumental participation in the author's professional development. His unwavering support, counsel, insight, and valuable time were treasured. What a privilege to be supervised by a gifted, wise, humble man who has positively impacted thousands of lives in his 40 years of counselling. All 20 of the author's practicum clients benefited considerably. May his recently published book, Healing for the Heart and the Spirit, bless all who read and apply its pearls of wisdom. Moreover, if it wasn't for him and his recommendation to study the influential works of Dr. Charles Solomon, the author would have overlooked educational resources that were life-giving to her calling and work with her case study subject. To him, the author gives honour. May powerful fruit harvest in the lives of those who come to her for counsel.

The author also want to acknowledge Yorkville University’s highly academic and challenging Master's Program and the many professors who have helped prepare her for work as a counsellor. Without its convenient online educational structure for people who cannot attend the traditional "brick and mortar" environment of fulltime studies, the author would not have had the privilege of completing her Master of Arts in Counselling Psychology degree.

\section{References}

Akin, A., \& Çetin, B. (2007). The Depression Anxiety Stress Scale (DASS): The Study of Validity and Reliability. Educational Sciences: Theory \& Practice, 7, 260-268. http://search.ebscohost.com/login.aspx?direct=true\&AuthType=url,cookie,ip,uid\&db=ehh\&AN=24374470

American Psychiatric Association (APA) (2013). Diagnostic and Statistical Manual of Mental Disorders (5th ed.). Arlington, VA: Author.

Appleby, D. W., \& Ohlschlager, G. (2013). Transformative Encounters: The Intervention of God in Christian Counseling and Pastoral Care. Westmount, IL: Intervarsity Press.

Aten, J. D., McMinn, M. R., \& Worthington, E. L. (2011). Spiritually Oriented Interventions for Counselling and Psychotherapy. Washington DC: American Psychological Association. http://dx.doi.org/10.1037/12313-000

Bonn-Miller, M. O., Vujanovic, A. A., Boden, M. T., \& Gross, J. J. (2011). Posttraumatic Stress, Difficulties in Emotion Regulation, and Coping-Oriented Marijuana Use. Cognitive Behavioural Therapy, 40, 34-44

http://search.ebscohost.com/login.aspx?direct=true\&AuthType=url,cookie,ip,uid\&db=a9h\&AN=58528454 http://dx.doi.org/10.1080/16506073.2010.525253

Breslau, N., \& Anthony, J. C. (2007). Gender Differences in the Sensitivity to Posttraumatic Stress Disorder: An Epidemiological Study of Urban Young Adults. Journal of Abnormal Psychology, 116, 607-611.

http://search.ebscohost.com/login.aspx?direct=true\&AuthType=url,cookie,ip,uid\&db=pdh\&AN=2007-11737-017 http://dx.doi.org/10.1037/0021-843X.116.3.607

Breslau, N., Davis, G. C., Andreski, P., \& Peterson, E. (1991). Traumatic Events and Posttraumatic Stress Disorder in an Urban Population of Young Adults. Archives of General Psychiatry, 48, 216-222. 
http://archpsyc.jamanetwork.com/article.aspx?articleid=495250

Brewin, C. R., Andrews, B., \& Valentine, J. D. (2000). Meta-Analysis of Risk Factors for Posttraumatic Stress Disorder in Trauma-Exposed Adults. Journal of Consulting and Clinical Psychology, 68, 748-766.

http://search.ebscohost.com/login.aspx?direct=true\&AuthType=url,cookie,ip,uid\&db=pdh\&AN=2000-02835-001 http://dx.doi.org/10.1037//0022-006X.68.5.748

Bromet, E., Sonnega, A., \& Kessler, R. C. (1998). Risk factors for DSM-III-R Posttraumatic Stress Disorder: Findings from the National Comorbidity Survey. American Journal of Epidemiology, 147, 353-361.

http://aje.oxfordjournals.org/content/147/4/353.full.pdf+html http://dx.doi.org/10.1093/oxfordjournals.aje.a009457

Brown, J. M., Williams, J. Bray, R. M., \& Hourani, L. (2012). Postdeployment Alcohol Use, Aggression, and Post-Traumatic Stress Disorder, Military Medicine, 177, 1184-1190. http://search.ebscohost.com/login.aspx?direct=true\&AuthType=url,cookie,ip,uid\&db=a9h\&AN=82283364

Burns, D. D. (1999). The Feeling Good Handbook (Rev. ed.). New York, NY: Plume/Penguin Group.

Burns, J. L., Lee, R. M., \& Brown, L. J. (2011). The Effect of Meditation on Self-Reported Measures of Stress, Anxiety, Depression, and Perfectionism in a College Population. Journal of College Student Psychotherapy, 25, 132-144. http://search.ebscohost.com/login.aspx?direct=true\&AuthType=url,cookie,ip,uid\&db=a9h\&AN=59836239 http://dx.doi.org/10.1080/87568225.2011.556947

Carroll, K. M., Ball, S. A., Martino, S., Nich, C., Babuscio, T. A., Nuro, K. F., \& Rounsaville, B. J. (2008). Computer-Assisted Delivery of Cognitive-Behavioral Therapy for Addiction: A Randomized Trial of CBT4CBT. The American Journal of Psychiatry, 165, 881-888.

http://search.ebscohost.com/login.aspx?direct=true\&AuthType=url,cookie,ip,uid\&db=a9h\&AN=33254480 http://dx.doi.org/10.1176/appi.ajp.2008.07111835

Casado-Kehoe, M., \& Kehoe, M. P. (2007). Using Genograms Creatively To Promote Healthy Lifestyles. Journal of Creative Mental Health, 2, 19-29.

http://search.ebscohost.com/login.aspx?direct=true\&AuthType=url,cookie,ip,uid\&db=a9h\&AN=31849501 http://dx.doi.org/10.1300/J456v02n04_03

Collins, G. (2007). Christian Counseling (3rd ed.). Dallas, TX: Nelson.

Collins, J. L., Ellickson, P. L., \& Klein, D. J. (2007). The Role of Substance Use in Young Adult Divorce. Addiction, 102, 786-794. http://search.ebscohost.com/login.aspx?direct=true\&AuthType=url,cookie,ip,uid\&db=a9h\&AN=24732435 http://dx.doi.org/10.1111/j.1360-0443.2007.01803.x

Cox, R. B., Ketner, J. S., \& Blow, A. J. (2013). Working with Couples and Substance Abuse: Recommendations for Clinical Practice. The American Journal of Family Therapy, 41, 160-172. http://dx.doi.org/10.1080/01926187.2012.670608 http://search.ebscohost.com/login.aspx?direct=true\&AuthType=url,cookie,ip,uid\&db=a9h\&AN=85879143

Crawford, J. R., \& Henry, J. D. (2003). The Depression Anxiety Stress Scales (DASS): Normative Data and Latent Structure in a Large Non-Clinical Sample. British Journal of Clinical Psychology, 42, 111-131.

http://search.ebscohost.com/login.aspx?direct=true\&AuthType=url,cookie,ip,uid\&db=a9h\&AN=10100708 http://dx.doi.org/10.1348/014466503321903544

Depoy, J. (1999). Bipolar Disorder: A Family-Focused Treatment Approach. Psychiatric Rehabilitation Journal, 23, 196197. http://dx.doi.org/10.1037/h0095168 http://search.ebscohost.com/login.aspx?direct=true\&AuthType=url,cookie,ip,uid\&db=a9h\&AN=2841125

Elijah House (2009). Elijah House Healing Trauma Resource. Coeur d’Alene, ID: Author.

Elijah House (2011). School of Ministry Training Course 201: Level 1 Prayer Ministry. Coeur d’Alene, ID: Author.

Elijah House (2012). School of Ministry Training Course 202: Level 1 \& 2 Prayer Ministry. Coeur d’Alene, ID: Author.

Elijah House (2013). Life History Questionnaire. Coeur d'Alene, ID: Author.

Fals-Stewart, W. (2013). Substance Abuse and Intimate Relationships. American Association for Marriage and Family Therapy. http://www.aamft.org/imis15/content/Consumer_Updates/Substance_Abuse_and_Intimate_Relationships.aspx

Fawcett, J., Golden, B., \& Rosenfeld, N. (2007). New Hope for People with Bipolar Disorder: Your Friendly, Authoritative Guide to the Latest in Traditional and Complementary Solutions (Revised 2nd ed.). New York: Three Rivers Press.

Follette, V. C., \& Ruzek, J. (2006). Cognitive-Behavioral Therapies for Trauma (2nd ed.). New York: Guilford Press.

Friends in Recovery (1988). Twelve-Steps: A Spiritual Journey. Scotts Valley, CA: Author.

Goldenberg, H., \& Goldenberg, I. (2013). Family Therapy (8th ed.). Belmont, CA: Brooks/Cole, Cengage Learning.

Goldstein, B. E., Strober, M. A., Birmaher, B., Axelson, D. A., Esposito-Smythers, C., Goldstein, T. R. et al. (2008). Substance Abuse Use Disorders among Adolescents with Bipolar Spectrum Disorders. Bipolar Disorders, 10, 469-478. 
http://search.ebscohost.com/login.aspx?direct=true\&AuthType=url,cookie,ip,uid\&db=a9h\&AN=31842157 http://dx.doi.org/10.1111/j.1399-5618.2008.00584.x

Goleman, D. (1994). Emotional Intelligence: Why It Can Matter More than IQ. New York: Bantam Books.

Goodson, A. H. (2012). Spiritual Intelligence (2nd ed.). Tucson, AZ: Author.

Hamblen, J. L. (2013). PTSD 101 Courses: What Is PTSD? http://www.ptsd.va.gov/professional/ptsd101/course-modules/what-is-ptsd.asp\#

Hamblen, J. L., Jankowski, M. K., Rosenberg, S. D., \& Mueser, K. T. (2004). Cognitive-Behavioral Treatment of PTSD in People with Severe Mental Illness: Three Case Studies. American Journal of Psychiatric Rehabilitation, 7, 147-170. http://search.ebscohost.com/login.aspx?direct=true\&AuthType=url,cookie,ip,uid\&db=a9h\&AN=15219357 http://dx.doi.org/10.1080/15487760490476192

Hoge, C. W., Auchterlonie, J. L., \& Milliken, C. S. (2006). Mental Health Problems, Use of Mental Health Services, and Attrition from Military Service after Returning from Deployment to Iraq or Afghanistan. The Journal of American Medical Association (JAMA), 295, 1023-1032. http://jama.jamanetwork.com/article.aspx?articleid=202463 http://dx.doi.org/10.1001/jama.295.9.1023

Hovell-Dew, M. A. (2006). Emotional Transformation: A Workbook and Manual. Maitland, FL: Xulon Press.

Hussain, D. (2011). Spirituality, Religion, and Health: Reflections and Issues. Europe's Journal of Psychology, 7, $187-197$. http://search.ebscohost.com/login.aspx?direct=true\&AuthType=url,cookie,ip,uid\&db=pxh\&AN=676132011-011 http://dx.doi.org/10.1037/e676132011-011

Kessler, R. C., Chiu, W. T., Demler, O., \& Walters, E. E. (2005). Prevalence, Severity, and Comorbidity of 12-Month DSMIV Disorders in the National Comorbidity Survey Replication. Archives of General Psychiatry, 62, 617-627. http://archpsyc.jamanetwork.com/article.aspx?articleid=208671 http://dx.doi.org/10.1001/archpsyc.62.6.617

Kessler, R. C., Sonnega, A., Bromet, E., Hughes, M., \& Nelson, C. B. (1995). Posttraumatic Stress Disorder in the National Comorbidity Survey. Archives of General Psychiatry, 52, 1048-1060. http://archpsyc.jamanetwork.com/article.aspx?articleid=497313

Kilpatrick, D. G., Acierno, R., Resnick, H. S., Saunders, B. E., \& Best, C. (1997). A 2-Year Longitudinal Analysis of the Relationships between Violent Assault and Substance Use in Women. Journal of Consulting and Clinical Psychology, 65, 834-847.

http://search.ebscohost.com/login.aspx?direct=true\&AuthType=url,cookie,ip,uid\&db=pdh\&AN=1997-05068-012

Kilpatrick, D. G., Ruggiero, K. J., Acierno, R., Saunders, B. E., Resnick, H. S., \& Best, C. L. (2003). Violence and Risk of PTSD, Major Depression, Substance Abuse/Dependence, and Comorbidity: Results from the National Survey of Adolescents. Journal of Consulting and Clinical Psychology, 71, 692-700. http://dx.doi.org/10.1037/0022-006X.71.4.692 http://www.apa.org/pubs/journals/releases/ccp-714692.pdf

Koenig, H. G. (2009). Research on Religion, Spirituality, and Mental Health. Canadian Journal of Psychiatry, 54, $283-291$. http://search.ebscohost.com/login.aspx?direct=true\&AuthType=url,cookie,ip,uid\&db=a9h\&AN=41223676

Kosten, T. R., Jalali, B., Hogan, I., \& Kleber, H. D. (1983). Family Denial as a Prognostic Factor in Opiate Addict Treatment Outcome. Journal of Nervous and Mental Disease, 171, 611-616.

http://journals.lww.com/jonmd/Abstract/1983/10000/Family_Denial_as_a_Prognostic_Factor_in_Opiate.4.aspx http://dx.doi.org/10.1097/00005053-198310000-00004

Klystra, C., \& Klystra, B. (2001). Restoring the Foundations: An Integrated Approach to Healing Ministry (2nd ed.). Hendersonville, NC: Restoring the Foundations Publications.

Lagerberg, T. V., Sundet, K., Aminoff, S. R., Berg, A. O., Ringen, P. A., Andreassen, O. A., \& Melle, I. (2011). Excessive Cannabis Use Is Associated with Earlier Age at Onset in Bipolar Disorder. European Archives of Psychiatry and Clinical Neuroscience, 261, 397-405. http://dx.doi.org/10.1007/s00406-011-0188-4 http://search.ebscohost.com/login.aspx?direct=true\&AuthType=url,cookie,ip,uid\&db=pbh\&AN=64481416

Larsson, S., Aas, M., Klungsoyr, O., Agartz, I., Mork E., Steen, N. E. et al. (2013). Patterns of Childhood Adverse Events Are Associated with Clinical Characteristics of Bipolar Disorder. BMC Psychiatry, 13, 1-9.

http://search.ebscohost.com/login.aspx?direct=true\&AuthType=url,cookie,ip,uid\&db=a9h\&AN=87442477 http://dx.doi.org/10.1186/1471-244X-13-97

Lenz, G., Berg, A., Breit-Gabauer, B., Demelbauer, S., Stampfer, Aigner, M. et al. (2009). Cognitive Behavior Therapy (CBT) versus Psychoeducation (PE) in Bipolar Disorder: A Randomized Controlled Study. Bipolar Disorders, 11 (suppl. 1), 9-13. http://dx.doi.org/10.1111/j.1399-5618.2009.00694.x http://www.onlinelibrary.wiley.com

Lim, S. L., \& Nakamoto, T. (2008). Genograms: Use in Therapy with Asian Families with Diverse Cultural Heritages. Contemporary Family Therapy, 30, 199-219. http://dx.doi.org/10.1007/s10591-008-9070-6 
http://search.ebscohost.com/login.aspx?direct=true\&AuthType=url,cookie,ip,uid\&db=a9h\&AN=34649989

Lovibond, S. H., \& Lovibond, P. F. (1995). Manual for the Depression Anxiety Stress Scales (2nd ed.). Sydney: Psychology Foundation. http://www.acpmh.unimelb.edu.au/site_resources/Trainingthe authornitiativeDocuments/follow-up/DASS.pdf

Maguire, C., McCusker, C. G., Meenagh, C., Mulholland, C., \& Shannon, C. (2008). Effects of Trauma on Bipolar Disorder: The Meditational Role of Interpersonal Difficulties and Alcohol Dependence. Bipolar Disorders, 10, $293-302$. http://search.ebscohost.com/login.aspx?direct=true\&AuthType=url,cookie,ip,uid\&db=a9h\&AN=28831779 http://dx.doi.org/10.1111/j.1399-5618.2007.00504.x

Matsakis, A. (1996). I Can't Get over It: A Handbook for Trauma Survivors (2nd ed.). Oakland, CA: New Harbinger.

McVey, S., \& Quarles, M. (2012). Helping Others Overcome Addictions: How God’s Grace Brings Lasting Freedom. Eugene, OR: Harvest House.

Merikangas, K. R., Akiskal, H. S., Angst, J., Greenberg, P. E., Hirschfield, R. M. A., Petukhova, M., \& Kessler, R. C. (2007). Lifetime and 12-Month Prevalence of Bipolar Spectrum Disorder in the National Comorbidity Survey Replication. Archives of General Psychiatry, 64, 543-552. http://archpsyc.jamanetwork.com/article.aspx?articleid=482285

http://dx.doi.org/10.1001/archpsyc.64.5.543

Miklowitz, D. J. (2008). Bipolar Disorder: A Family-Focused Treatment Approach (2nd ed.). New York: Guilford Press.

Miklowitz, D. J. (2011). The Bipolar Disorder Survival Guide: What You and Your Family Need to Know (2nd ed.). New York: Guilford Press.

Miklowitz, D. J. (2012). Family Treatment for Bipolar Disorder and Substance Abuse in Late Adolescence. Journal of Clinical Psychology, 68, 502-513. http://dx.doi.org/10.1002/jclp.21855 http://search.ebscohost.com/login.aspx?direct=true\&AuthType=url,cookie,ip,uid\&db=pbh\&AN=74281482

Miller, S., Miller, P., Nunnally, E. W., \& Wackman, D. B. (1991). Couple Communication I: Talking and Listening Together. Littleton, CO: Interpersonal Communication Programs.

Mueser, K. T., Rosenberg, S. D., Jankowski, M. K., Hamblen, J. L., \& Monica, D. (2004). A Cognitive-Behavioral Treatment Program for Posttraumatic Stress Disorder in Persons with Severe Mental Illness. American Journal of Psychiatric Rehabilitation, 7, 107-146. http://dx.doi.org/10.1080/15487760490476183 http://search.ebscohost.com/login.aspx?direct=true\&AuthType=url,cookie,ip,uid\&db=a9h\&AN=15219353

Murphy, E. (1992). The Handbook for Spiritual Warfare (Revised and Updated). Nashville, TN: Nelson.

Najavits, L. M., Weiss, R. D., Shaw, S. R., \& Muenz, L. R. (1998). “Seeking Safety”: Outcome of a New Cognitive-Behavioral Psychotherapy for Women with Posttraumatic Stress Disorder and Substance Dependence. Journal of Traumatic Stress, 11, 437-456. http://dx.doi.org/10.1023/A:1024496427434 http://search.ebscohost.com/login.aspx?direct=true\&AuthType=url,cookie,ip,uid\&db=a9h\&AN=964253

National Institute on Drug Abuse (NIDA) (2010). Comorbidity: Addiction and Other Mental Illnesses. http://www.drugabuse.gov/sites/default/files/rrcomorbidity.pdf

Nelson, A. E. (2010). Spiritual Intelligence: Discover Your SQ. Deepen Your Faith. Grand Rapids, MI: Baker Books.

Newberg, A. B. (2011). Spirituality and the Aging Brain. Journal of the American Society on Aging, 35, 83-91. http://search.ebscohost.com/login.aspx?direct=true\&AuthType=url,cookie,ip,uid\&db=a9h\&AN=66815080

Norris, F. H. (1992). Epidemiology of Trauma: Frequency and Impact of Different Potentially Traumatic Events on Different Demographic Groups. Journal of Consulting and Clinical Psychology, 60, 409-418.

http://search.ebscohost.com/login.aspx?direct=true\&AuthType=url,cookie,ip,uid\&db=pdh\&AN=1992-31484-001

Otto, M. W., Perlman, C. A., Wernicke, R., Reese, H. E., Bauer, M. S., \& Pollack, M. H. (2004). Posttraumatic Stress Disorder in Patients with Bipolar Disorder: A Review of Prevalence, Correlates, and Treatment Strategies. Bipolar Disorders, 6, 470-479. http://search.ebscohost.com/login.aspx?direct=true\&AuthType=url,cookie,ip,uid\&db=a9h\&AN=15067324 http://dx.doi.org/10.1111/j.1399-5618.2004.00151.x

Ozer, E. J., Best, S. R., Lipsey, T. L., \& Weiss, D. S. (2008). Predictors of Posttraumatic Stress Disorder and Symptoms in Adults: A Meta-Analysis. Psychological Trauma: Theory, Research, Practice, and Policy, S, 3-36. http://search.ebscohost.com/login.aspx?direct=true\&AuthType=url,cookie,ip,uid\&db=pdh\&AN=2008-10829-002

Perkinson, R. R. (2012). Chemical Dependency Counseling: A Practical Guide (4th ed.). Thousand Oaks, CA: SAGE.

Perlick, D. A., Miklowitz, D. J., Lopez, N., Chou, J., Kalvin, C., Adzhiashvili, V., \& Aronson, A. (2010). Family-Focused Treatment for Caregivers of Patients with Bipolar Disorder. Bipolar Disorders, 12, 627-637. http://search.ebscohost.com/Login.aspx?direct=true\&AuthType=url,cookie,ip,uid\&db=a9h\&AN=66356175

Pringle, B. (2013). Healing for the Heart and the Spirit. Victoria: Friesen Press.

Rea, M. M., Miklowitz, D. J., Tompson, M. C., Goldstein, M. J., Hwang, S., \& Mintz, J. (2003). Family-Focused Treatment versus Individual Treatment for Bipolar Disorder: Results of a Randomized Clinical Trial. Journal of Consulting and Cli- 
nical Psychology, 71, 482-492. http://dx.doi.org/10.1037/0022-006X.71.3.482

http://search.ebscohost.com/login.aspx?direct=true\&AuthType=url,cookie,ip,uid\&db=a9h\&AN=9974712

Resnick, H. S., Kilpatrick, D. G., Dansky, B. S., Saunders, B. E., \& Best, C. L. (1993). Prevalence of Civilian Trauma and Posttraumatic Stress Disorder in a Representative National Sample of Women. Journal of Consulting and Clinical Psychology, 61, 984-991. http://search.ebscohost.com/login.aspx?direct=true\&AuthType=url,cookie,ip,uid\&db=pdh\&AN=1994-25706-001

Richards, P. S., \& Bergin, A. E. (2005). A Spiritual Strategy for Counseling and Psychotherapy (2nd ed.). Washington DC: American Psychological Association. http://dx.doi.org/10.1037/11214-000

Sandford, J. L., \& Sandford, M. (2008). Deliverance and Inner Healing (Rev. ed.). Grand Rapids, MI: Chosen Books.

Scazzero, P. (2006). Emotionally Healthy Spirituality. Nashville, TN: Nelson.

Schafer, G. (2011). Family Functioning in Families with Alcohol and Other Drug Addiction. Social Policy Journal of New Zealand, 37, 1-17.

http://www.msd.govt.nz/about-msd-and-our-work/publications-resources/journals-and-magazines/social-policy-journal/spj 37/37-family-functioning-in-families-with-alcohol-and-other-drug-addiction.html

Schiraldi, G. R. (2009). The Posttraumatic Stress Disorder Sourcebook (2nd ed.). New York: McGraw Hill.

Schneider-Corey, M., Corey, G., \& Corey, C. (2010). Groups Process and Practice (8th ed.). Belmont, CA: Brooks/Cole Cengage Learning.

Smith, P. A. (2012). From Generation to Generation: A Manual for Healing (4th ed.). Westport, MA: Generational Healing Ministries.

Solomon, C. R. (1991). Handbook to Happiness and You: A Spiritual Clinic. Denver, CO: Exchanged Life Foundation.

Sperry, L. (2012). Spirituality in Clinical Practice: Theory and Practice of Spiritually Oriented Psychotherapy (2nd ed.). New York: Routledge/Taylor.

Steinbuchel, P. H., Wilens, T. E., Adamson, J. J., \& Sgambati, S. (2009). Posttraumatic Stress Disorder and Substance Use Disorder in Adolescent Bipolar Disorder. Bipolar Disorders, 11, 198-204.

http://search.ebscohost.com/login.aspx?direct=true\&AuthType=url,cookie,ip,uid\&db=a9h\&AN=36635619 http://dx.doi.org/10.1111/j.1399-5618.2008.00652.x

Stewart, S. H. (1996). Alcohol Abuse in Individuals Exposed to Trauma: A Critical Review. Psychological Bulletin, 120, 83-112.

http://search.ebscohost.com/login.aspx?direct=true\&AuthType=url,cookie,ip,uid\&db=pdh\&AN=1996-01403-005 http://dx.doi.org/10.1037/0033-2909.120.1.83

Sullivan, A. E., \& Miklowitz, D. J. (2010). Family Functioning among Adolescents with Bipolar Disorder. Journal of Family Psychology, 24, 60-67. http://dx.doi.org/10.1037/a0018183 http://search.ebscohost.com/login.aspx?direct=true\&AuthType=url,cookie,ip,uid\&db=pdh\&AN=2010-02774-008

Underwood, L. G., \& Teresi, J. (2002). The Daily Spiritual Experience Scale (DSES): Development, Theoretical Description, Reliability, Exploratory Factor Analysis, and Preliminary Construct Validity Using Health Related Data. Annals of Behavioral Medicine, 24, 22-33. http://www.dsescale.org/underwoodteresi.pdf http://dx.doi.org/10.1207/S15324796ABM2401 04

Wadsworth, R., Spampneto, A. M., \& Halbrook, B. M. (1995). The Role of Sexual Trauma in the Treatment of Chemically Dependent Women: Addressing the Relapse Issue. Journal of Counseling and Development, 73, 401-406.

http://search.ebscohost.com/login.aspx?direct=true\&AuthType=url,cookie,ip,uid\&db=a9h\&AN=9506040005 http://dx.doi.org/10.1002/j.1556-6676.1995.tb01772.x

Willow, R. A., Tobin, D. J., \& Toner, S. (2009). Assessment of the Use of Spiritual Genograms in Counselor Education. Counseling and Values, 53, 214-223. http://dx.doi.org/10.1002/j.2161-007X.2009.tb00127.x http://search.ebscohost.com/login.aspx?direct=true\&AuthType=url,cookie,ip,uid\&db=a9h\&AN=37220595

Wright, N. H. (2011). The Complete Guide to Crisis and Trauma Counseling. Ventura, CA: Regal.

Zaretsky, A., Lancee, W., Miller, C., Harris, A., \& Parikh, S. V. (2008). The Authors Cognitive-Behavioural Therapy More Effective than Psychoeducation in Bipolar Disorder? Canadian Journal of Psychiatry, 53, 441-448. http://search.ebscohost.com/login.aspx?direct=true\&AuthType=url,cookie,ip,uid\&db=a9h\&AN=33625653 